\title{
Aberrant epigenetic modifications in the CTCF binding domain of the IGF2/H19 gene in prostate cancer compared with benign prostate hyperplasia
}

\author{
AGNIESZKA PARADOWSKA ${ }^{1}$, IRINA FENIC ${ }^{1}$, LUTZ KONRAD ${ }^{2}$, KLAUS STURM ${ }^{3}$, \\ FLORIAN WAGENLEHNER $^{1}$, WOLFGANG WEIDNER ${ }^{1}$ and KLAUS STEGER $^{1}$ \\ Departments of ${ }^{1}$ Urology and Pediatric Urology, ${ }^{2}$ Obstetrics and Gynecology, \\ ${ }^{3}$ Institute of Pathology, Justus Liebig University, Giessen, Germany
}

Received February 6, 2009; Accepted April 22, 2009

DOI: 10.3892/ijo_00000316

\begin{abstract}
Expression of the imprinted genes insulin-like growth factor 2 (IGF2) and H19 depends on the methylation pattern of their common imprinting control region (ICR) located on chromosome 11p15. As the somatic imprinting pattern may be lost during tumorigenesis due to epigenetic alterations, in the present study, we analyzed the DNA methylation and histone modifications in the differentially methylated region (DMR) of IGF2/H19 in benign prostate hyperplasia (BPH) and prostate carcinoma ( $\mathrm{PCa})$. Sodium bisulfite sequencing was performed on frozen tissue collected after radical prostatectomy. Thirty tumors and 17 noncancerous tissue samples were analyzed. Histological diagnosis was, in addition, confirmed by amplification of the epithelial tumor marker $\alpha$-methylacyl coenzyme-A racemase. Chromatin immunoprecipitation assay (ChIP) was carried out on sonificated chromatin from fresh tissue samples from $10 \mathrm{PCa}, 10 \mathrm{BPH}$ using antibodies against trimethyl histone $\mathrm{H} 3 \mathrm{~K}$ 9, dimethyl histone $\mathrm{H} 3 \mathrm{~K}$ 9, trimethyl H3K27 and acetyl H3K9. The methylation pattern of $17 \mathrm{CpGs}$ within $227 \mathrm{bp}$ of the H19 fragment was characterized from each DNA sample. All (BPH) samples demonstrated $>80 \%$ methylation of CpGs. In contrast, we found $41 \%$ of CpGs methylated in 9 out of $30 \mathrm{PCa}$ specimens. We observed statistically significant differences in the methylation state between PCa and BPH groups, especially in the DMR of H19 $(\mathrm{p}<0.0001)$ and in the ICR $(\mathrm{p}=0.0034)$, which corresponds to CTCF binding domain. ChIP assay revealed that dimethyl H3K9 is associated with the ICR of IGF2/H19 in BPH, but not in PCa $(\mathrm{p}<0.0001)$. Our data demonstrate that DNA methylation and histone methylation analysis of the ICR within the DMR of IGF2/H19 provides important insights
\end{abstract}

Correspondence to: Dr Agnieszka Paradowska, Department of Urology and Pediatric Urology, Justus-Liebig University, RudolfBuchheim-Str. 7, 35385 Giessen, Germany

E-mail: agnieszka.paradowska@chiru.med.uni-giessen.de

Key words: genomic imprinting, DNA methylation, post-translational modification of histones, prostate cancer, prostatic hyperplasia into early steps of carcinogenesis and, therefore, may contribute to improving diagnosis of $\mathrm{PCa}$.

\section{Introduction}

Insulin-like growth factor 2 (IGF2) and H19 are two reciprocally imprinted genes, which are implicated in the etiology of many solid tumors including prostate cancer (PCa). Expression of the IGF2 gene is achieved from the paternal allele, whereas the putative tumor suppressor gene H19 is expressed from the maternal allele $(1,2)$ (Fig. 1). In a variety of tumors, however, this imprinting pattern may be lost due to epigenetic modifications $(3,4)$. There is evidence that the differentially methylated region (DMR) which includes the imprinting control region (ICR), located from -2226 to -1999 upstream of the H19 transcriptional start site, is involved in regulating this parent of origin-specific expression by means of a methylation-sensitive binding of the CCCTC-binding factor (CTCF) (5). The transcription factor CTCF exhibits 11 zinc fingers that mediate specific binding to unmethylated $\mathrm{CpG}$ islands within the H19 DMR containing 7 potential CTCF binding sites. Furthermore, CTCF acts as a chromatin insulator that blocks the activity of the proximal IGF2 promoter by insulating it from the distal enhancers located downstream to H19. Thus, on the unmethylated maternal allele, CTCF binds to generate a boundary that prevents the IGF2 promoter from accessing the enhancer resulting in silencing of IGF2, but supports transcription of H19. The paternally inherited allele maintains a methylated ICR, which prevents CTCF binding, therefore, enhancers and transcription factors can be recruited to the IGF2 promoter providing the epigenetic switch of IGF2 (6-8).

It has been demonstrated that loss of methylation within the ICR of IGF2/H19 is correlated with loss of imprinting in Wilm's tumors (9) osteosarcoma $(10)$ colorectal cancer $(11,12)$ and bladder cancer (13). LOI for IGF2 occurs in the mouse as well as in human prostate associated with increased IGF2 expression during aging. In older animals, expression of the chromatin insulator protein $\mathrm{CTCF}$ and its binding to the IGF2/H19 imprint control was found to be reduced. IGF2 LOI occurs with aging in histologically normal human prostate tissues and epigenetic alteration was determined to be more 
extensive in men with associated cancer (14). Besides CpG methylation in the ICR of imprinted genes, chromatin looping enables the expression of IGF2 from the paternal allele by juxtaposing the distal enhancer with the IGF2 promoter (15). Furthermore, the secondary chromatin structure with histone modifications has been proposed to be sufficient in establishing the imprinting state. However, the accurate mechanistic manner of histone regulatory effect on imprinting state still remains unclear.

Prostate cancer is a significant health problem in the Western countries because of its high incidence and mortality (16). Unfortunately, there is still a lack of effective prognostic markers to predict the behaviour of prostate cancer. Present biomarkers including preoperative prostate-specific antigen (PSA) and biopsy Gleason score have not proved to be accurate predictors of clinical outcome (17). About $25 \%$ of men with normal PSA may harbour PCa and PSA $<20 \mathrm{ng} / \mathrm{ml}$ may not differentiate between PCa and benign conditions (18).

Successful therapy of PCa is based on the existence of prognostic biomarkers that are able to predict the behaviour of the cancer at an early stage of development so that appropriate treatments could be administered to the patient. The two features of early event in tumorigenesis and the potential reversibility make epigenetic modifications a promising target for diagnosis, risk stratification and treatment.

In the present study, we therefore determined possible changes in DNA methylation associated with tumorigenesis in the prostate analyzing the methylation pattern of the DMR of IGF2/H19 in both PCa and benign prostate hyperplasia (BPH). Finally, chromatin immunoprecipitation (ChIP) assays with antibodies to di-/tri-methyl H3K9, tri-methyl H3K27 and acetyl $\mathrm{H} 3$ were performed to determine possible changes in the histone modification within the ICR of IGF2/H19 as a possible clinical application in early diagnosis of $\mathrm{PCa}$.

\section{Patients and methods}

Clinical and pathological characteristics of prostate cancer patients. Tissue samples from $30 \mathrm{PCa}$ and $17 \mathrm{BPH}$ surrounding tumors were obtained from patients who underwent either radical prostatectomy or cystoprostatectomy at the Department of Urology and Pediatric Urology, University of Giessen, Germany. All patients provided written informed consent for using the material for research purposes.

Prostate carcinoma grade (Gleason score) was determined by histological examination, Institute of Pathology, University of Giessen, Germany. The characteristics of all PCa patients including age of patient, preoperative level of prostate-specific antigen (PSA), Gleason score and tumor staging (pT) are shown in Table I.

PCa patients were between 56 and 79 years (mean $=65.5$ years). The majority of patients revealed tumors with Gleason score 7 ( 8 of total $30 \mathrm{PCa}$ patients $=26.6 \%)$. The level of serum PSA before radical prostatectomy was $>20 \mathrm{ng} / \mathrm{ml}$ in 12 out of 30 patients. Organ-confined tissue T2 staging was diagnosed in 15 out of 30 patients and extra capsular T3 in 8 out of 30 patients (Table II).

Human prostate tissue samples. Only samples in which at least $70 \%$ of the cells represented cancer epithelial cells were selected for this study. Additionally, the expression of the tumor epithelial cell marker $\alpha$-methylacyl-CoA racemase (AMACR) was determined to differentiate between PCa and BPH. For DNA methylation analysis, genomic DNA was isolated from frozen tissue sections using Qiamp DNA mini kit (Qiagen, Hilden, Germany). For chromatin immunoprecipitation (ChIP) assay, native, fresh tissue samples were subjected to crosslinking immediately after surgery and then stored at $-80^{\circ} \mathrm{C}$.

$R T-P C R$. AMACR expression was evaluated by semiquantitative RT-PCR. Total RNA was extracted using RNeasy mini kit, according to the manufacturer's instruction (Qiagen). cDNA was prepared from $2 \mu \mathrm{g}$ of RNA using the Omniscript Reverse Transcription System (Qiagen) with random primers. cDNA $(2 \mu 1)$ was used for the PCR-reaction. Amplification was performed with 1 unit Taq DNA polymerase (Qiagen) in $50 \mathrm{ml}$ volume for 40 cycles on a thermocycler (Bio-Rad, Munich, Germany) with AMACR and HALAS as housekeeping gene, as indicated in Table III. After an initial heating to $95^{\circ} \mathrm{C}$ for $4 \mathrm{~min}$, each of the 40 cycles consisted of denaturing at $95^{\circ} \mathrm{C}$ for $45 \mathrm{sec}$, annealing at $63^{\circ} \mathrm{C}$ for $45 \mathrm{sec}$ and elongation at $72^{\circ} \mathrm{C}$ for $90 \mathrm{sec}$ except for the last extension which lasted 5 min. PCR products were separated on $1 \%$ agarose gels and stained with GelRed (Biotium, Biotrend, Cologne, Germany).

Immunohistochemistry. For detection of primary antibodies, the labelled polymer-based EnVision+ system-HRP (Dako) was used. Slides from PCa patients were incubated in a dry oven for $1 \mathrm{~h}$ at $60^{\circ} \mathrm{C}$, deparaffinised, rehydrated and incubated with $3 \% \mathrm{H}_{2} \mathrm{O}_{2}$ for 6 min. After washing three times for $5 \mathrm{~min}$ in phosphate-buffered saline (PBS), slides were incubated in 1X target retrieval solution $\mathrm{pH} 6.1$ (Dako) for $30 \mathrm{~min}$ at $94^{\circ} \mathrm{C}$ in a steamer (Multigourmet F510, Braun, Kronberg, Germany). Unspecific binding sites were blocked by incubating the slides in freshly prepared 2\% skim milk for 20 min (Fluka, Buchs, Switzerland). The primary monoclonal antibody AMACR (1:100, Biologo, Kronshagen, Germany) was added and incubated for $1 \mathrm{~h}$ at room temperature in a humidified chamber. After washing with PBS, the respective secondary antibodies coupled to the EnVision+ peroxidase-conjugated polymer (Dako) were added and the slides incubated for $30 \mathrm{~min}$ in a humidified chamber. After washing with PBS, detection was performed using 3,3'-diaminobenzidine tetrahydrochloride (K3468, Liquid DAB+, Dako) and monitored microscopically. Sections were then washed with PBS and counterstained with hematoxylin. Documentation of the results was performed with an Axiovert 200 microscope equipped with an AxioCam digital camera and pictures were documented with MRGrab 1.0 (Carl Zeiss, Munich, Germany).

Sodium bisulfite treatment and DNA sequencing. Genomic DNA $(2 \mu \mathrm{g})$ was treated with sodium bisulfite using EpiTect Bisulfit kit (Qiagen) according to the manufacturer's instructions. Sodium bisulfite converts unmethylated cytosines to uracils, whereas methylated cytosines are unaffected. Bisulfite-treated DNA was subsequently amplified using H19for (corresponding to nucleotides 6099-6121, GenBank accession no. AF087017) and H19rev (nucleotides 6326-6303) are listed in Table IV. These primers allow the amplification of 
Table I. Characteristics of PCa patients.

\begin{tabular}{|c|c|c|c|c|c|c|}
\hline No. & Age (years) & PSA (ng/ml) & Gleason score & pT staging & Methylation of DMR ${ }^{\mathrm{a}}$ & Methylation of $\mathrm{ICR}^{\mathrm{b}}$ \\
\hline 1 & 70 & 10.1 & $2+4=6$ & $\mathrm{pT} 2 \mathrm{a}$ & $5 / 17$ & $3 / 5$ \\
\hline 2 & 75 & 28.4 & $5+4=9$ & pT3b & $4 / 17$ & $2 / 5$ \\
\hline 3 & 73 & 30.6 & $4+5=9$ & pT3b & $2 / 17$ & $5 / 5$ \\
\hline 4 & 56 & 34.7 & $2+9=5$ & $\mathrm{pT} 2 \mathrm{a}$ & $6 / 17$ & $4 / 5$ \\
\hline 5 & 73 & 29.1 & $2+3=5$ & $\mathrm{pT} 2 \mathrm{~b}$ & $2 / 17$ & $5 / 5$ \\
\hline 6 & 79 & 2.4 & $4+4=8$ & pT2b & $2 / 17$ & $5 / 5$ \\
\hline 7 & 64 & 9.8 & $3+4=7$ & pT3b & $3 / 17$ & $1 / 5$ \\
\hline 8 & 68 & 34.6 & $4+4=8$ & pT3a & $2 / 17$ & $5 / 5$ \\
\hline 9 & 56 & 34.7 & $3+2=5$ & $\mathrm{pT} 2 \mathrm{a}$ & $3 / 17$ & $4 / 5$ \\
\hline 10 & 64 & 2.9 & $4+3=7$ & pT2b & $2 / 17$ & $5 / 5$ \\
\hline 11 & 59 & 22.0 & $4+3=7$ & pT3a & $2 / 17$ & $1 / 5$ \\
\hline 12 & 60 & 11.5 & $3+3=6$ & pT $2 \mathrm{c}$ & $2 / 17$ & $1 / 5$ \\
\hline 13 & 70 & 10.8 & $3+4=7$ & pT3b & $7 / 17$ & $3 / 5$ \\
\hline 14 & 56 & 33.5 & $2+3=5$ & pT $2 a$ & $3 / 17$ & $1 / 5$ \\
\hline 15 & 67 & 19.0 & $3+4=7$ & pT3b & $4 / 17$ & $2 / 5$ \\
\hline 16 & 59 & 19.7 & $3+4=7$ & pT $2 \mathrm{c}$ & $4 / 17$ & $3 / 5$ \\
\hline 17 & 73 & 10.8 & $4+4=8$ & $\mathrm{pTa}$ & $4 / 17$ & $2 / 5$ \\
\hline 18 & 63 & 22.5 & $4+2=6$ & pT1a & $6 / 17$ & $4 / 5$ \\
\hline 19 & 59 & 15.5 & $4+5=9$ & $\mathrm{pT} 2 \mathrm{a}$ & $5 / 17$ & $3 / 5$ \\
\hline 20 & 60 & 21.0 & $2+3=5$ & pT1c, G2 & $5 / 17$ & $4 / 5$ \\
\hline 21 & 69 & 30.5 & $3+3=6$ & $\mathrm{pT} 2 \mathrm{~b}, \mathrm{G} 2$ & $4 / 17$ & $2 / 5$ \\
\hline 22 & 70 & 12 & $3+3=6$ & pT2c & $6 / 17$ & $4 / 5$ \\
\hline 23 & 62 & 6.61 & $3+3=6$ & pT1c & $3 / 17$ & $1 / 5$ \\
\hline 24 & 70 & 4.9 & $3+4=7$ & pT1c & $6 / 17$ & $4 / 5$ \\
\hline 25 & 62 & 17 & $3+3=7$ & pT1c & $7 / 17$ & $5 / 5$ \\
\hline 26 & 60 & 10 & $4+4=8$ & $\mathrm{pT} 2 \mathrm{a}$ & $6 / 17$ & $4 / 5$ \\
\hline 27 & 60 & 25 & $4+4=8$ & pT2b & $2 / 17$ & $0 / 5$ \\
\hline 28 & 71 & 10.2 & $3+2=5$ & pT1c & $4 / 17$ & $2 / 5$ \\
\hline 29 & 75 & 11.3 & $2+3=5$ & $\mathrm{pT} 2 \mathrm{a}$ & $4 / 17$ & $2 / 5$ \\
\hline 30 & 62 & 7 & $4+4=8$ & pT3a & $5 / 17$ & $3 / 5$ \\
\hline
\end{tabular}

${ }^{\text {aN }}$ umber of methylated CpGs in entire DMR fragment consisting of $17 \mathrm{CpGs} .{ }^{\mathrm{b}}$ Number of methylated CpGs within ICR composed of five CpGs.

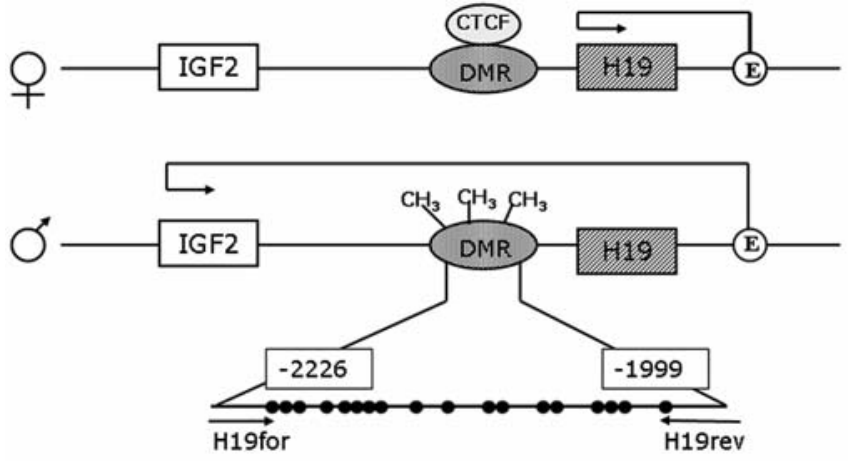

Figure 1. Genomic imprinting at the IGF2/H19 locus. While the IGF2 gene exhibits maternal imprinting resulting in the expression of the paternal allele, the non-coding RNA gene $\mathrm{H} 19$ reveals paternal imprinting that is followed by the expression of the maternal allele. A differentially methylated region (DMR) on the paternal allele $\sim 2 \mathrm{~kb}$ upstream of the H19 promoter represents the imprinting centre, the deletion of which results in loss of imprinting of both genes. On the unmethylated maternal allele, the imprinting centre provides multiple binding sites for the enhancer (E) blocking protein $\mathrm{CTCF}$, which assembles a boundary element to prevent access of downstream enhancers to the IGF2 promoters. On the paternal allele, methylation inhibits CTCF-binding allowing the enhancers to act exclusively on the IGF2 promoter. For further information see (6) and (7). Arrows indicate transcription. both the methylated and the unmethylated alleles by spanning a region with 17 differentially methylated CpGs.

DNA was amplified in a $30 \mu 1$ volume containing $10 \mu 1$ of the extracted and bisulphite-treated DNA, PCR buffer gold, $1.5 \mathrm{mM} \mathrm{MgCl}_{2}, 0.2 \mathrm{mM}$ of each dNTP, $0.66 \mu \mathrm{M}$ of each primer and $0.5 \mu 1(2.5 \mathrm{U})$ of Amplitaq Gold polymerase (Qiagen). After activation of the polymerase at $95^{\circ} \mathrm{C}$ for $10 \mathrm{~min}$, DNA was amplified in 40 cycles for $45 \mathrm{sec}$ at $95^{\circ} \mathrm{C}$, $56^{\circ} \mathrm{C}$ and $72^{\circ} \mathrm{C}$ followed by a final extension at $72^{\circ} \mathrm{C}$ for $10 \mathrm{~min}$. Each PCR product $(5 \mathrm{ml})$ was analyzed on agarose gel and the remaining $25 \mu 1$ were purified using QIAquick purification kit (Qiagen). The probes were then subjected to sequencing using forward primer by Scientific Research and Development GmbH, Oberursel, Germany. The sequencing results were analyzed using BiQ Analyzer, a software tool for DNA methylation available by free download from http://biq-analyzer.bioinf.mpi-inf.mpg.de/.

Chromatin immunoprecipitation (ChIP). Immediately after surgery, native $\mathrm{PCa}$ and $\mathrm{BPH}$ tissue samples were used for analysis of the histone $\mathrm{H} 3$ methylation status. Prior to crosslinking, $100 \mathrm{mg}$ of tissue was cut into $\sim 3 \mathrm{~mm}^{3}$ pieces 
Table II. Summary of clinical and pathological characteristics of PCa patients.

\begin{tabular}{|c|c|c|}
\hline & \multicolumn{2}{|c|}{ Prostate cancer } \\
\hline & $\mathrm{n}$ & $\%$ \\
\hline \multicolumn{3}{|l|}{ Gleason score } \\
\hline 5 & 7 & 23.3 \\
\hline 6 & 6 & 20 \\
\hline 7 & 8 & 26.6 \\
\hline 8 & 6 & 20 \\
\hline 9 & 3 & 10 \\
\hline \multicolumn{3}{|l|}{$\begin{array}{l}\text { Preoperative } \\
\text { serum PSA }(\mathrm{ng} / \mathrm{ml})\end{array}$} \\
\hline$<4$ & 2 & 0.6 \\
\hline $4.0-12$ & 12 & 40 \\
\hline $12-20$ & 4 & 13.3 \\
\hline$>20$ & 12 & 40 \\
\hline \multicolumn{3}{|l|}{ pT staging } \\
\hline $\mathrm{T} 1$ & 7 & 23.3 \\
\hline $\mathrm{T} 2$ & 15 & 50 \\
\hline $\mathrm{T} 3$ & 8 & 26.6 \\
\hline $\mathrm{T} 4$ & 0 & 0 \\
\hline Mean age in years (range) & 65.5 & $(56-79)$ \\
\hline
\end{tabular}

with a razor blade. Minced tissue was then placed into a 15 $\mathrm{ml}$ concical tube and $10 \mathrm{ml}$ of PBS buffer was added. Crosslinking was carried out by addition of formaldehyde to a final concentration of $1 \%$ and incubation of samples for $15 \mathrm{~min}$ on a rotating platform at room temperature following a 15 min incubation with $0.125 \mathrm{M}$ glycin in order to stop the crosslinking (19). Samples were then centrifuged at $200 \mathrm{x} g$ for $5 \mathrm{~min}$ to pellet the tissue pieces, supernatant was removed.
The tissue pieces were washed with cold PBS. After washing steps, supernatant was completely removed from the tube and fixed tissues were frozen at $-20^{\circ} \mathrm{C}$ for storage. Tissue pieces in $2 \mathrm{ml}$ of PBS buffer containing protease inhibitors were disaggregated by 20 strokes in an Ultra Turrax homogenizer (IKA, Staufen, Germany). The resulting mixture was centrifuged at 2,000 x g, the supernatant was decanted and the cell pellet was resuspended in $4 \mathrm{ml}$ of ChIP lysis buffer (Upstate Biotechnology, Lake Placid, NY). Homogenized tissue extract ( $1 \mathrm{ml}$ pro tube) was sonicated 12 times on ice with a Branson 250 sonifier on setting 3, duty cycle $50 \%$ for 30 secs to an average length of $\sim 500-1000 \mathrm{bp}$.

Sonicated chromatin was diluted 10 -fold with provided dilution buffer and $1 \mathrm{ml}$ of the probe was precleared with $40 \mu \mathrm{l}$ of salmon sperm DNA/protein A agarose solution before overnight incubation at $4^{\circ} \mathrm{C}$ with antibodies and controls (no antibody immunoprecipitation). Ten percent of sonicated chromatin $(100 \mu \mathrm{l})$ was saved for each sample to determine the input chromatin amount. Specific antibodies used for immunoprecipitation were purchased from Abcam (Cambrige, UK) and recognized histone $\mathrm{H} 3$ (ab1791), di-methyl histone H3K9 (ab 7312), tri-methyl histone H3K9 (ab8898), tri-methyl histone H3K27 (ab6002) and acetyl histone H3K9 (ab4441). After addition of $40 \mu \mathrm{l}$ of salmon sperm DNA/protein A agarose solution, samples were incubated for further $2 \mathrm{~h}$. The beads were washed with the buffers provided by the kit. Chromatin was eluted twice with $250 \mu 1$ elution buffer (1\% SDS in $0.1 \mathrm{M} \mathrm{NaHCO}_{3}$ ). Crosslinks were reversed by adding $5 \mathrm{M} \mathrm{NaCl}$ and incubating at $65^{\circ} \mathrm{C}$ for $4 \mathrm{~h}$ followed by proteinase $\mathrm{K}$ digestion for $1 \mathrm{~h}$ at $45^{\circ} \mathrm{C}$. DNA was extracted by phenol/chloroform treatment, ethanol precipitation with $3 \mu \mathrm{l}$ glycogen as inert carrier, resuspended in $30 \mu 1 \mathrm{TE}$ buffer and stored at $-20^{\circ} \mathrm{C}$. The enrichment of immunoprecipitated probe (IP) was analysed using quantitative real-time reverse transcription PCR. The amplification of IP DNA was carried out in $25 \mu 1$ reaction volume on the iCycler iQ real-time PCR Detection System (Bio-Rad). The final reaction tube

Table III. Primer pairs used in this study.

\begin{tabular}{|c|c|c|c|}
\hline Primers & Sequence $\left(5^{\prime}-3^{\prime}\right)$ & Annealing temperature $\left({ }^{\circ} \mathrm{C}\right)$ & Product size $(b p)$ \\
\hline \multicolumn{4}{|c|}{ Primer sequences used for semiquantitative RT-PCR } \\
\hline AMACR-F & ACGACGTGAGCCGCTTGGG & 62 & 183 \\
\hline AMACR-R & GCCTTGGATTTTCCCGCTGC & & \\
\hline HALAS-F & AGGCCAAGGTCCAACAGACT & 62 & 217 \\
\hline HALAS-R & АССТСТTTССTCACGGCATTC & & \\
\hline \multicolumn{4}{|c|}{ Primer sequences used for bisulfite DNA sequencing } \\
\hline H19-F & GTATAGTATATGGGTATTTTTGG & 56 & 227 \\
\hline H19-R & СТАТАААТАТССТАТТСССАААТА & & \\
\hline \multicolumn{4}{|c|}{ Primer sequences used for chromatin immunoprecipitation } \\
\hline H19-ChIP-F & GAGGCTTCTCCTTCGGTCTC & 64 & 239 \\
\hline H19-ChIP-R & GATAATGCCCGACCTGAAGA & & \\
\hline GAPDH-F & TGGTATCGTGGAAGGACTCAT & 64 & 189 \\
\hline GAPDH-R & ATGCCAGTGAGCTTCCCGTTCA & & \\
\hline
\end{tabular}

$\mathrm{F}$, forward primer and $\mathrm{R}$, reverse primer. 


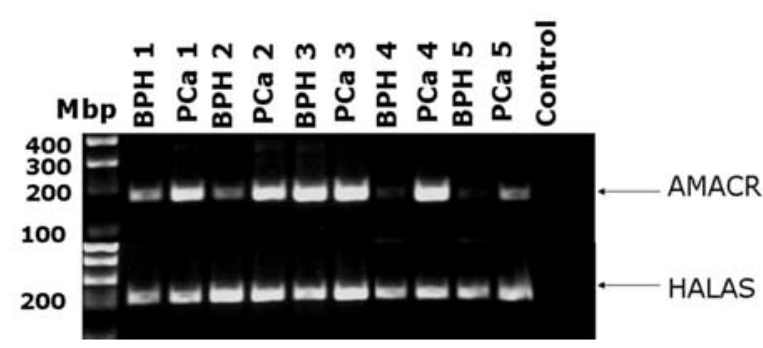

Figure 2. mRNA expression of AMACR in prostate tissue sections. BPH samples with high expression of AMACR were excluded from the study due to contamination of tumor cells (e.g. BPH 3). PCa demonstrates a 2-3-fold higher AMACR expression when compared with BPH. HALAS was used as a house-keeping gene.

contained $100 \mathrm{nM}$ of $\mathrm{H} 19$ primers and house-keeping gene GAPDH (Table III) $12.5 \mu \mathrm{l}$ iQ SYBR-Green Supermix (Bio-Rad) and $2 \mu \mathrm{l}$ of DNA template. The PCR conditions were $94^{\circ} \mathrm{C}$ for $3 \mathrm{~min}$ followed by 40 cycles for $30 \mathrm{sec}, 60^{\circ} \mathrm{C}$ for $30 \mathrm{sec}$ and $72^{\circ} \mathrm{C}$ for $1 \mathrm{~min}$. Melting curves were generated for both genes after amplification. Negative controls were included in each run. The enrichment of the IP probe was calculated as fold enrichment relative to Input (10\% of untreated chromatin): \% relative enrichment of $\mathrm{IP}=2^{\text {(Input -IP) }} \times 10 \%$. PCR-products were additionally electrophoresed on a 3\% agarose gel and visualized by GelRed reagent.

Statistics. Values from all experiments were used for calculation of the means and their respective standard errors of the mean (SEM). The non-parametric test of Mann-Whitney was used to determine significant differences between the different experimental groups by using GraphPad Instat 3 (GraphPad, San Diego, USA). P-values $<0.05$ were considered statistically significant.

\section{Results}

High expression level of AMACR indicates tumor cells in prostate tissue sections. To verify tissue homogeneity in both $\mathrm{PCa}$ and $\mathrm{BPH}$ sections, only PCa samples displaying $>70 \%$ tumor epithelial cells in $\mathrm{H} \& \mathrm{E}-$ stained slides were included in this study. BPH samples that contained contaminations of tumor cells or high grade prostatic intraepithelial neoplasia (PIN) were excluded. In samples with controversial histological diagnosis, we performed both RT-PCR (Fig. 2) and immunohistochemistry (Fig. 3) for AMACR, which is known to be consistently up-regulated in $\mathrm{PCa}$, but not in BPH. We demonstrated a 2-3-fold higher AMACR expression in 30 out of 38 analyzed $\mathrm{PCa}$ when compared with BPH exemplarily shown for 10 samples in Fig. 2. In contrast, $17 \mathrm{BPH}$ tissues exhibited low AMACR expression when compared with the house-keeping gene HALAS. However, AMACR expression was upregulated in $4 \mathrm{BPH}$ samples suggesting contamination with PCa cells as shown for 2 samples in Fig. 2.

Loss of methylation in the imprinting control region of the IGF2/H19 gene in PCa. Sodium bisulfite treatment followed by sequencing was performed on genomic DNA obtained from frozen tissue collected after radical prostatectomy. PCa samples $(n=30)$ and BPH samples $(n=17)$ were analyzed for the methylation of the DMR region containing $18 \mathrm{CpG}$ nucleotides (Fig. 1). The methylation state of $17 \mathrm{CpGs}$ within $227 \mathrm{bp}$ of the H19 fragment was characterized from each DNA sample after sequencing. All BPH samples exhibited $>80 \%$ methylation of CpGs (Fig. 4). Four out of 10 samples exhibited hypermethylation, where all CpGs were methylated. However, 3 unmethylated $\mathrm{CpG}$ islands were found in 3 out of $10 \mathrm{BPH}$ samples. In contrast, none of the $30 \mathrm{PCa}$ samples were completely methylated. Loss of methylation was indicated in at least 2 CpGs in the PCa group. One PCa sample revealed even 6 out of 17 unmethylated cytosines within the analyzed
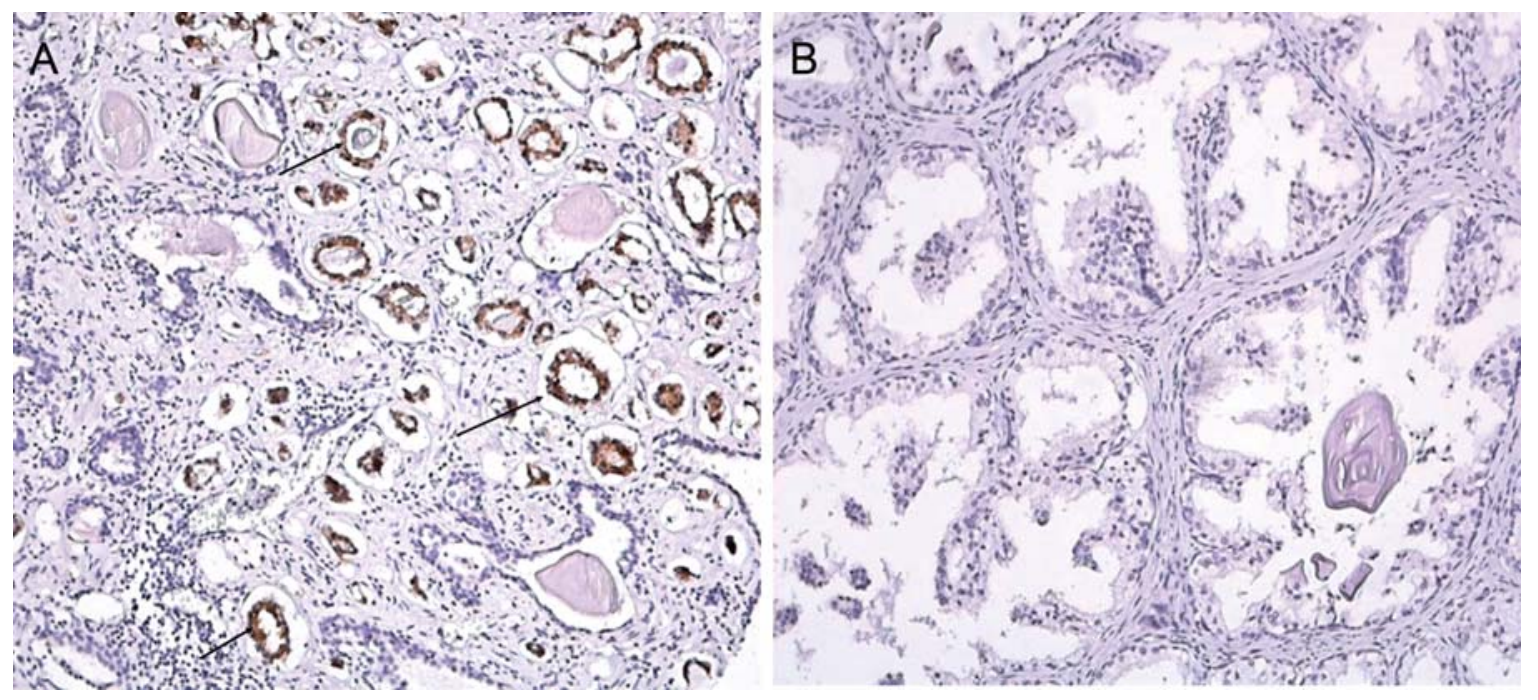

Figure 3. Immunohistochemical analysis demonstrated an increased expression of AMACR in malignant prostate epithelia relative to benign epithelia. (A) Image of PCa sample, Gleason score 6 carcinoma showing punctate cytoplasmatic staining of AMACR in basal epithelial cells (indicated by arrows). (B) Negative staining of normal appearing prostate glands in a BPH sample. 
Table IV. Correlation between CpG island methylation of DMR and ICR of H19 with clinical and histologic variables in prostate carcinoma patients.

\begin{tabular}{|c|c|c|c|c|}
\hline \multicolumn{5}{|c|}{ CpGs methylation of IGF2/H19 imprinting region (\%) } \\
\hline & DMR (17 CpGs) & P-value & ICR (5 CpGs) & P-value \\
\hline Age & mean $\pm \mathrm{SE}$ & \multirow{3}{*}{0.785} & mean $\pm \mathrm{SE}$ & \multirow{3}{*}{0.191} \\
\hline$<70$ & $81.77 \pm 2.39(n=10)$ & & $46 \pm 10.77(n=10)$ & \\
\hline$\geq 70$ & $78.42 \pm 4.96(\mathrm{n}=6)$ & & $23.3 \pm 10.85(\mathrm{n}=6)$ & \\
\hline \multicolumn{5}{|c|}{ PSA ng/ml } \\
\hline$\leq 20$ & $25.8 \pm 2.2(n=18)$ & \multirow[t]{2}{*}{0.121} & $58.9 \pm 6.36(n=18)$ & \multirow[t]{2}{*}{0.597} \\
\hline$>20$ & $20 \pm 2.66(n=12)$ & & $61.7 \pm 10.3(n=12)$ & \\
\hline \multicolumn{5}{|c|}{$\begin{array}{l}\text { Stage } \\
\text { (tumor node metastasis) }\end{array}$} \\
\hline $\mathrm{T} 1-\mathrm{T} 2$ & $24.1 \pm 2.2(n=20)$ & \multirow[t]{2}{*}{0.66} & $63 \pm 7(n=20)$ & \multirow[t]{2}{*}{0.43} \\
\hline T3-T4 & $22.3 \pm 3.0(n=10)$ & & $54 \pm 8.97(n=10)$ & \\
\hline \multicolumn{5}{|c|}{ Gleason score } \\
\hline$\leq 7$ & $24.6 \pm 2.13(n=21)$ & \multirow[t]{2}{*}{0.364} & $58.1 \pm 6.31(n=21)$ & \multirow[t]{2}{*}{0.54} \\
\hline$>7$ & $20.87 \pm 3.12(n=9)$ & & $64.4 \pm 11.4(\mathrm{n}=9)$ & \\
\hline
\end{tabular}

region. The other PCa samples displayed a lack of methylation in 2-5 CpG sites. The difference in methylation of DMR of $\mathrm{H} 19$ between BPH and PCa was statistically significant $(\mathrm{p}=0.0087)$. The avarage number of unmethylated $\mathrm{CpG}$ islands in DMR of the PCa group was 2-fold higher when compared with loss of methylation in the BPH group (Fig. 5). Moreover, we observed differences in the methylation state between $\mathrm{PCa}$ and $\mathrm{BPH}$, especially in the ICR containing a core binding domain for the methylation-specific enhancer CTCF. The percentage of unmethylated $\mathrm{CpGs}$ in ICR of the $\mathrm{PCa}$ group was 3 -fold higher than in ICR of the BPH group $(p=0.0034)$ (Fig. 5).

Histone H3 modification at the IGF/H19 imprinting region in PCa compared with BPH. To determine, whether loss of DNA methylation within the IGF/H19 ICR in PCa, as demonstrated in this study, is in addition associated with changes in histone methylation, we studied the histone $\mathrm{H} 3$ methylation pattern at lysines 9 and 27, as well as H3 acetylation using ChIP assay. The enrichment of IP probe was measured using specific primers for H19 region and GAPDH by real-time PCR. Finally enrichment of the IP probe was expressed as percentage of untreated input chromatin. Our results revealed that dimethyl H3K9 is associated with the ICR of IGF2/H19 in BPH, but not in PCa (Fig. 6 ). The enrichment of anti-dimethyl H3K9 antibodies in IGF/H19 imprinting region was 3-fold higher in $\mathrm{BPH}(3.88 \%)$ than in PCa $(1.30 \%)$. The statistical comparison of PCa group $(n=10)$ and BPH $(n=10)$ was confirmed as highly significant $(\mathrm{p}<0.0001)$. High enrichment of anti-dimethyl H3K9 antibodies suggests that di-methyl H3K9 might be associated with the ICR of IGF/H19 in normal prostate tissue. In contrast, there was very low enrichment of anti-dimethyl H3K9 antibodies in PCa that suggests no binding of dimethyl H3K9 to IGF/H19 imprinting region in PCa tissue. We did not detect any differences in binding of trimethyl $\mathrm{H} 3 \mathrm{~K} 9$, to the IGF/H19 imprinting region, neither in $\mathrm{PCa}$, nor in BPH. The same results were obtained using anti-tri-methyl H3K27 and anti-acetyl H3 antibodies (Fig. 6).

\section{Discussion}

In the present study, we demonstrated significant differences in the DNA methylation pattern of the CTCF binding sites within the H19 ICR in PCa when compared with BPH.

Five $\mathrm{CpGs}$ of the ICR revealed at least one unmethylated $\mathrm{CpG}$ island in the majority of the PCa samples, whereas no more than one unmethylated $\mathrm{CpG}$ island could be found in the $\mathrm{BPH}$ group (control). Besides the ICR, hypermethylation of the entire H19 DMR was observed in both the PCa and the $\mathrm{BPH}$ group. Our results raise the question of possible mechanisms underlying loss of imprinting (LOI) at the IGF2/ H19 locus and progression of PCa. As LOI and biallelic expression of IGF2 and $\mathrm{H} 19$ has long been known as a common feature in many prostate cancer (20), we focused our investigations exclusively on methylation of these imprinted genes in tissue from $\mathrm{PCa}$.

In somatic cells, it has already been demonstrated that the differentially methylated ICR upstream of the H19 gene regulates allelic IGF2 expression by means of a methylationsensitive chromatin insulator function (21). The hypomethylated maternally inherited ICR binds the insulator protein CTCF at its binding domain and blocks the activity of the proximal IGF2 promoter by insulating it from its distal enhancers (22). CTCF binding to the H19 DMR, by contrast, is suppressed by DNA methylation (23). Similar results were obtained in BPH, where we demonstrated hypermethylation of the H19 ICR. In contrast, our results revealed loss of methylation in the ICR of PCa. These data support the hypothesis that loss of methylation in the H19 ICR in PCa may provoke binding of CTCF resulting in LOI and expression of the H19 gene from the paternal allele. A similar effect of reciprocal methylation changes at a critical CTCF-binding 
$\mathbf{A}$

$\mathrm{BPH}$

\begin{tabular}{|c|c|c|c|c|c|c|c|c|c|c|}
\hline 1오 & 오 & i & PQP & & 9 & 99 & & i & iq? & i \\
\hline $2+$ & 9 & s & P९९P & 9 & 9 & 91 & 1 & 1 & 919 & I \\
\hline 39 & 오 & i & 999 & $i$ & 9 & 99 & $i$ & $i$ & 99 & 9 \\
\hline 4 & 오 & 오. & ـ & 1 & 9 & 99 & 9 & 9 & 199 & 9 \\
\hline $5 \perp$ & 1 & 오 & iq99 & 1 & 1 & 99 & 1 & 1 & 199 & I \\
\hline $6 \perp$ & 오 & 오 & P99י & 9 & 9 & 99 & $i$ & 9 & "19? & 9 \\
\hline $7+$ & 9 & 1 & in? & 1 & 1 & 91 & 1 & 1 & ㅍํ & I \\
\hline $8+$ & 1 & 1 & 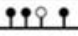 & 1 & 1 & 99 & $i$ & 1 & i甲 & 9 \\
\hline $9 \stackrel{\bullet}{1}$ & 1 & 9 & i999 & 9 & 9 & 99 & $i$ & 9 & iq & i \\
\hline 10 - & $i$ & $i$ & iq99 & i & i & 99 & $i$ & $i$ & iq1 & ค \\
\hline 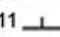 & 1 & 1 & Piepe & 1 & 1 & 99 & $\stackrel{1}{1}$ & $i$ & ำ? & i \\
\hline $12 \stackrel{1}{2}$ & 9 & 1 & i99? & 1 & 9 & 99 & 9 & 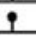 & 99 & 9 \\
\hline 13 오 & 오 & 1 & PQ9" & 1 & 9 & 19 & $i$ & 1 & i9? & ค \\
\hline 14_오 & is & i & Pैip & 9 & 9 & iq & $i$ & 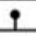 & i19 & i \\
\hline $15{ }^{\circ}$ & 9 & 9 & iथค & $i$ & 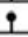 & 9 & $i$ & $i$ & 19 & i \\
\hline 16오 & 오 & ? & Pथ9 & 9 & 9 & 99 & 9 & i & 91 & i \\
\hline 17 & 우 & i & Pभ९ & 9 & 9 & 9 & & i & 9i? & i \\
\hline
\end{tabular}

Methylation

CpG Position

Unmethylated

Methylated

Not present
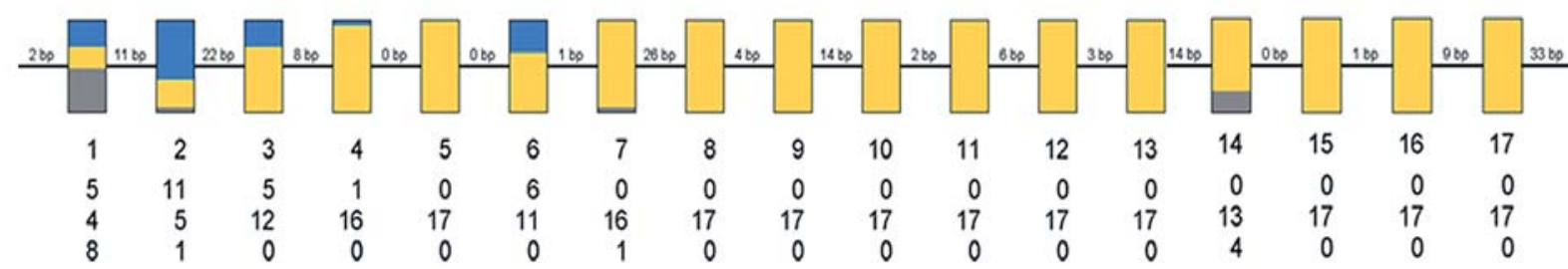

B

$\mathrm{PCa}$

\begin{tabular}{|c|c|c|c|c|c|c|c|c|c|c|}
\hline 198 & 8 & 8 & if? & & & iq & & i & IP & 9 \\
\hline 29 & 8 & $i$ & in & $i$ & $i$ & 19 & 9 & $i$ & if & $i$ \\
\hline 3 & 8 & 8 & ifi? & $i$ & $i$ & 19 & 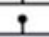 & $i$ & IT & $i$ \\
\hline$\sqrt[4]{9}$ & 8 & i & in? & $\varphi$ & i & 99 & $i$ & 9 & IP & 9 \\
\hline 5 & 8 & 8 & Pir? & 1 & i & 9 & 9 & 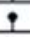 & 19 & 9 \\
\hline 6 오 & 8 & $i$ & ini? & i & i & 19 & $i$ & 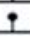 & 19 & i \\
\hline $7+1$ & i & P & isi" & 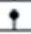 & $i$ & 19 & $i$ & $i$ & If & i \\
\hline 81 & 8 & 오 & Psip & $\varphi$ & i & $i 9$ & $i$ & 9 & it & 9 \\
\hline 9 오 & 8 & 8 & Pif, & 9 & $i$ & 99 & $i$ & 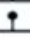 & $\mathrm{IPI}$ & 9 \\
\hline 10 오 & 8 & i & ini? & 9 & $i$ & 99 & $i$ & 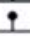 & if & 9 \\
\hline 111 & 8 & 오 & 989? & i & i & 9 & $i$ & 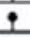 & if & i \\
\hline 12 & 8 & 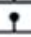 & in? & 9 & i & 99 & 9 & 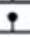 & iP & 9 \\
\hline $13+$ & 1 & 1 & ifip & $i$ & 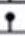 & 9 & $i$ & $i$ & 19 & i \\
\hline 14_ & 오 & i & ifi? & i. & i & 19 & $i$ & 1 & IP & i \\
\hline 15 & 8 & ? & 999? & $\varphi$ & 9 & 19 & 9 & $\varphi$ & iq & $\varphi$ \\
\hline $16+$ & 8 & 1 & if? & 1 & $i$ & 19 & $i$ & i & IP & 9 \\
\hline 17 工 & 8 & 8 & 998 & 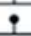 & 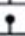 & 9 & $i$ & 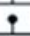 & ip & $i$ \\
\hline 18 & 1 & i & iㅛ요오 & 9 & i & 94 & $i$ & 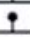 & if & i \\
\hline $19+9$ & 8 & ? & $989 ?$ & $\varphi$ & $P$ & 9 & 9 & $\varphi$ & ip & 9 \\
\hline 20 & 1 & 9 & ifi? & $i$ & $i$ & 9 & $i$ & $i$ & if & 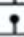 \\
\hline 211 & 8 & 9 & inf? & 9 & i & 19 & $i$ & 9 & $I 9$ & 9 \\
\hline $22+$ & 오 & $i$ & If? & 9 & $i$ & 99 & 9 & 9 & $\because P$ & 9 \\
\hline $23+$ & 8 & 9 & in? & 9 & i & 99 & I & 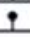 & IP & 9 \\
\hline 24 & i & 9 & 9819 & $\varphi$ & i & 19 & $i$ & i & IP & † \\
\hline $25 \dot{8}$ & 8 & P & ifi? & 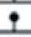 & 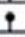 & 9 & 9 & 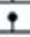 & if & i \\
\hline 26 & 8 & 8 & Sip? & & i & 9 & 9 & 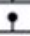 & iP & 9 \\
\hline 27 오 & 8 & 1 & ifit & 1 & $i$ & 19 & $i$ & 1 & $i t$ & i \\
\hline 28 & 8 & 8 & P甲9? & ${ }^{\circ}$ & 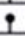 & 9 & 9 & $i$ & if & 9 \\
\hline $29+9$ & 8 & 9 & if? & 9 & i & 9 & $i$ & 9 & $\because 9$ & 9 \\
\hline 30 \& & 8 & $?$ & i99? & & 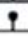 & 99 & & $\varphi$ & $\because 9$ & 9 \\
\hline
\end{tabular}

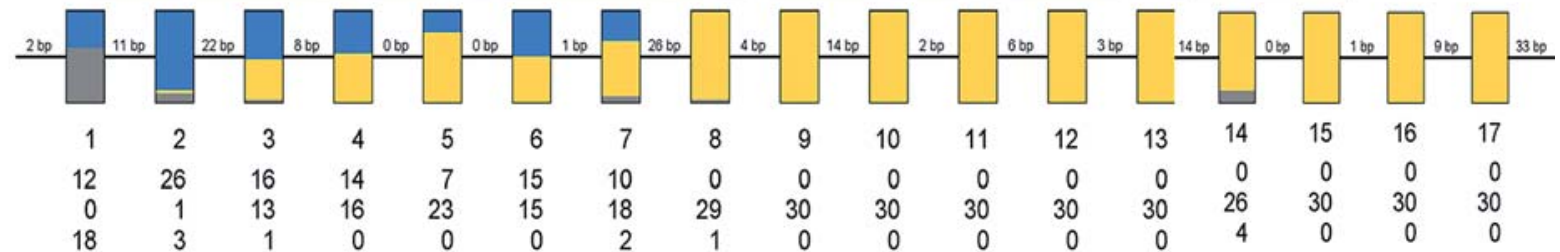

CpG Position

Unmethylated

Methylated

Not present

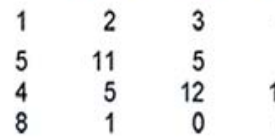

$\begin{array}{rrr}5 & 6 & 7 \\ 0 & 6 & 0 \\ 17 & 11 & 16 \\ 0 & 0 & 1\end{array}$

8
0
17
0

9
0
17
0

10
0
17
0

.

\section{Legend: $\quad$ unmethylated methylated not present}

Figure 4. Methylation analysis of H19 DMR in PCa and BPH using sodium bisulfite sequencing (SBS). Methylation pattern of H19 DMR in PCa and BPH samples (black circles correspond to methylated CpGs, open circles correspond to unmethylated CpGs, and small vertical lines without a circle correspond to non-CpG position where there is a $\mathrm{CpG}$ in the genomic sequence. Summary of the methylation status of each $\mathrm{CpG}$ in PCa and BPH. 


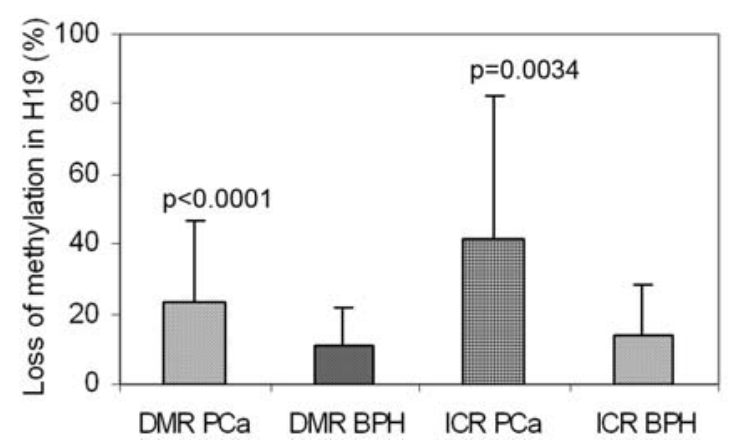

Figure 5. Correlation between $\mathrm{CpG}$ island methylation (\%) of DMR and ICR of H19 in PCa and BPH samples. Non-parametric Mann-Whitney test was used to compare the average of methylation in H19 DMR and ICR in $\mathrm{BPH}$ and $\mathrm{PCa}$.

site of the H19 locus was reported for the progression of osteosarcoma (10). Bisulfite sequencing data published by this group revealed that IGF2 LOI occurs with biallelic CpG methylation of the CTCF-binding site, while H19 LOI occurs with biallelic hypomethylation of this site. Moreover, IGF2 polymorphism analysis in tissues susceptible to age-related cancers, including $\mathrm{PCa}$, demonstrated a complete conversion of the IGF2 imprinting status from monoallelic to biallelic. As an underlying mechanism, a 2-fold decrease in the binding of the enhancer blocking element CTCF within the intergenic IGF2/H19 region has been suggested to cause this switch in senescent cells. The forced down-regulation of the CTCF expression using RNAi in prostate cell lines resulted in an increase of the IGF2 expression and a relaxation of imprinting $(14,15)$. Hypomethylation associated with LOI of Wilms Tumors 1 antisense regulatory region (WT1 ASS) and an alternative coding transcript AWT1 also occurs in the CTCF binding region and is apparent in nephrogenic rests suggesting an early impairment of methylation in kidney development followed by extensive demethylation during expansion of Wilms tumor (24). Aberrant hypomethylation of the CTCFbinding site in $\mathrm{IGF} / \mathrm{H} 19$ gene has been also reported in human bladder cancer which is in agreement with our results obtained in prostate cancer (13). Although authors have analysed methylation status of only six informative human bladder cases, they concluded that demethylation in the paternal allele, which was rare in normal tissue, might play a role in overexpression of H19 in advanced stage bladder cancer previously reported by Cooper et al (25). Our study provided statistically significant differences in methylation status between $30 \mathrm{PCa}$ and $17 \mathrm{BPH}$ samples is sufficient for supporting the hypothesis that the aberrant methylation of the sixth CTCF-binding site may influence abnormal expression of either IGF2 or H19 in PCa. The same phenomenon might also contribute to development of bladder cancer. On the basis of our data and recent reports from literature we assume that hypomethylation of CTCF regions of various imprinting genes including IGF2/H19 accompany LOI and may lead to the activation of tumor suppressor genes followed by carcinogenesis.
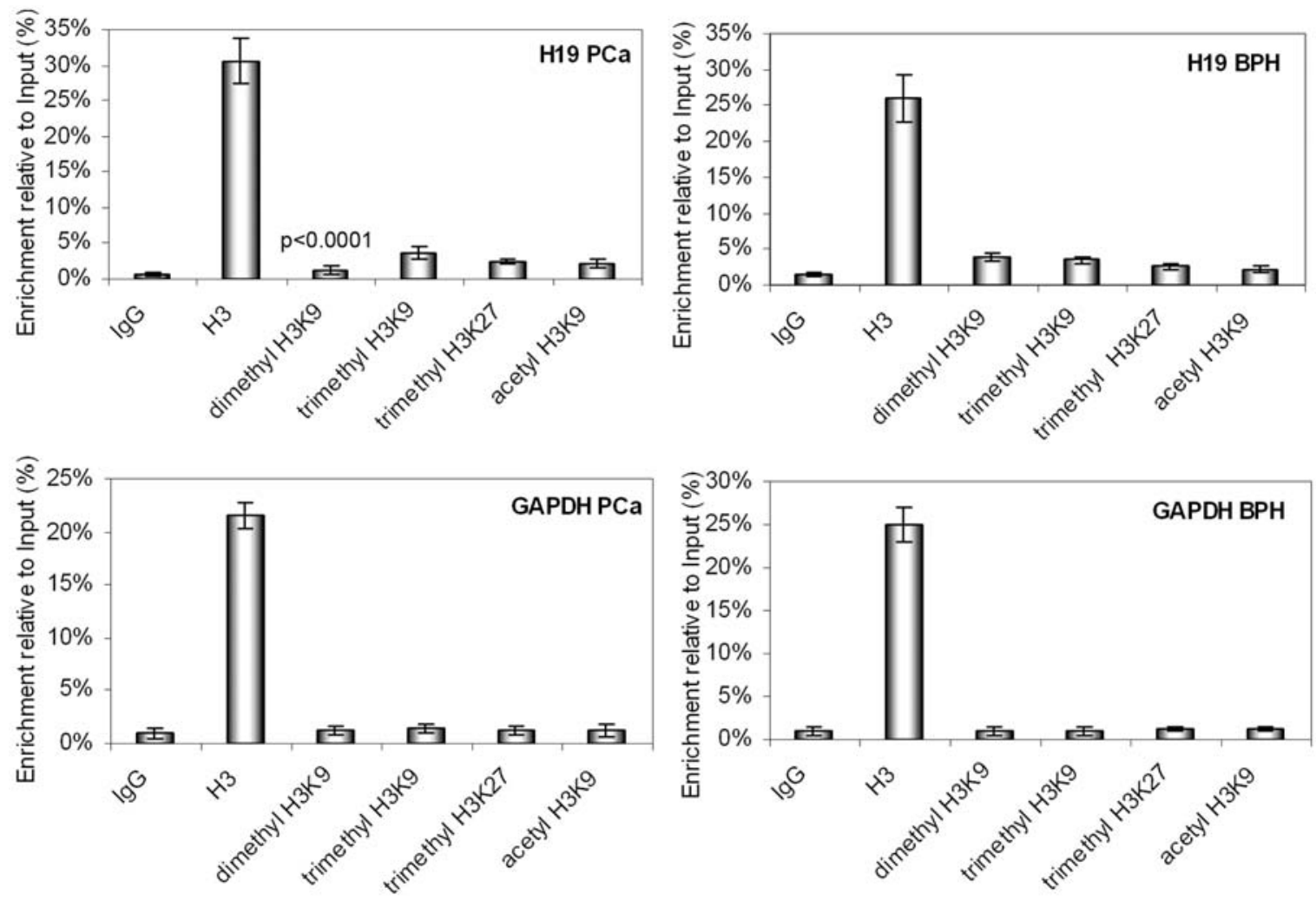

Figure 6. Epigenetic modification of histone H3 in PCa and BPH. ChIP assay using antibodies against dimethylated lysine-9 on histon H3 (H3K9 dimethyl), trimethylated lysine-9 on histon H3 (H3K9 trimethyl), trimethylated lysine-27 on histone H3 (H3K27 trimethyl) and acetylated lysine-9 on histone H3 (H3K9 acetyl) in chromatin from tissues of PCa patients $(n=10)$ and BPH controls $(n=10)$ was prepared. Anti-H3 antibodies were used as a positive control and rabbit IgG as a negative control. Input indicates not immunoprecipitated chromatin diluted 1:10. GAPDH amplification was used as reference gene. Enrichment of

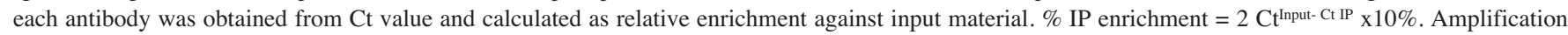
with $\mathrm{H} 19$ primers revealed that dimethyl H3K9 is associated with DMR of H19 in BPH, but not in PCa (p<0.0001, non-parametric Mann-Whitney test). 
Interestingly, we were able to demonstrate a lack of methylation of a single $\mathrm{CpG}$ within the H19 ICR in 4 out of 17 BPH samples. As epigenetic changes occur in early steps of carcinogenesis, lack of methylation within the H19 ICR of some patients exhibiting $\mathrm{BPH}$, in future, may advance our understanding of cancer development and may serve as prognostic biomarker to improve early diagnosis of $\mathrm{PCa}$. However, any powerful prognostic factor for PCa should correlate with clinicopathological parameters. Although we were able to demonstrate high statistical difference in the methylation status of the imprinting control region of IGF2/H19 between PCa and BPH, we could not find any statistical correlation of loss of methylation of ICR in and DMR in PCa patients either to their Gleason scores or to preoperative PSA values. There is a lack of information especially on methylation frequency of imprinted genes in association with recurrence parameters of $\mathrm{PCa}$, because the majority of studies provide studies on correlation of various promoter hypermethylation or hypomethylation to histological parameters (26). Possibly multiple analysis of methylation in more than one imprinted genes such as KCNQ1, LIT1, TSSC5, GRB10 and MEG3 may improve clinical significance. Studies presented by Ellinger et al (27) showed that hypermethylation at a single gene locus did not correlate with any clinicopathological variables. In contrast, hypermethylation at two genes (e.g., APC and TIG1, APC and GSTP1, APC and PTGS2, APC or MDR, GSTP1 or PTGS2) correlated significantly with the pathologic stage and/or Gleason score ( $\mathrm{p}=0.033$ to 0.045$)$.

Recent studies demonstrated that epigenetic control mechanisms involving DNA methylation and histone methylation may lead to the formation of a chromatin environment that inhibits transcription of several imprinted genes (28).

As tri-methyl H3K9 and tri-methyl H3K27 are known to be associated with inactive genes located within the heterochromatin $(29,30)$, our data confirm the hypothesis that this modification, in BPH, could be responsible for inactivation of H19 expression. Moreover, lack of DNA methylation in the ICR of IGF2/H19 together with no detectable level of dimethyl H3K9 in PCa might provoke binding of CTCF to this region resulting in enhanced expression of $\mathrm{H} 19$, the role of which in carcinogenesis is still unclear. Interestingly, recent study from Dobosy et al (31) provided evidence that folateand methyl-deficient diet causes decrease in di-methyl H3K9 modification within $\mathrm{H} 19$ promoter in prostate tissue of mature mice which also has been observed in our ChIP assay on human PCa tissue. Further studies investigating the relationship between DNA methylation, chromatin structure and DNA accessibility will provide insights into the epigenetic regulation of the IGF2/H19 locus in PCa. Several studies on epigenetics in $\mathrm{PCa}$ revealed that the aberration in posttranslational modifications of histones occur in cancer cells only at individual promoters and no statistically significant correlation to clinical outcome could be found (32-34). Seligson et al (35) used a combination of immunohistochemistry and tissue microarray to determine the level of H3K9ac, H3K18ac, H4K12ac, H4R3 dimethyl and H3K4 methyl in PCa tissue. Data indicated that $60 \%$ of the samples show positive staining with antibodies against di-methyl
H3K4. However, histone modifications differed between individual tissues. Nevertheless, it could be demonstrated that the global histone modification pattern can predict the risk of PCa recurrence.

Due to the heterogeneity of PCa tissue, it is difficult to avoid contamination by stromal cells surrounding the tumor. This may explain contradictory results in the literature regarding changes in the methylation pattern in PCa. In order to avoid false-positive and false-negative results caused by contamination with cancer epithelial cells in controls, we improved our investigations using $\alpha$-methylacyl coenzyme-A racemase (AMACR) as a molecular marker for $\mathrm{PCa}$ to support the histological diagnosis. AMACR catalyse peroxisomal $\beta$-oxidation of dietary branch chain fatty acids and $\mathrm{C}-27$ bile acid intermediates (36) and was reported to be overexpressed in PCa cells when compared with BPH cells $(37,38)$. Our immunohistochemical and RT-PCR data confirmed previous studies from Bull et al (39) and Luo (40) reporting that AMACR expression is $\sim 4$-fold higher in prostate cancer epithelial cells when compared with BPH and, therefore, represent an appropriate marker to differentiate tumor prostate sections from normal stromal cells.

In conclusion, the present study demonstrates significant differences in the DNA methylation pattern within the DMR of IGF2/H19. In particular, aberrant methylation of $\mathrm{CpG}$ nucleotides correspond to the CTCF binding domain of H19 in PCa. Furthermore, we demonstrated that dimethyl H3K9 is associated with the ICR of IGF2/H19 in BPH, but not in PCa. Understanding DNA methylation/demethylation and histone modifications in CTCF binding domain of imprinted genes in more detail will shed new light on carcinogenesis and will greatly help to improve prognosis and therapy of prostate cancer.

\section{Acknowledgements}

Funding of this research program was provided by the Else Kröner-Fresenius-Stiftung, Project P01/06/A76/05. The skilful technical assistance of Barbara Fröhlich is gratefully acknowledged.

\section{References}

1. Reik W and Walter J: Epigenetic reprogramming in mammalian development. Science 293: 1089-1093, 2001.

2. Reik W and Walter J: Genomic imprinting: parental influence on the genome. Nat Rev Genet 1: 21-32, 2001.

3. Rainier S, Johnson LA, Dobry CJ, Ping AJ, Grundy PE and Feinberg AP: Relaxation of imprinted genes in human cancer. Nature 362: 747-749, 1993.

4. Cui H, Cruz-Correa M, Giardiello FM, Hutcheon DF, Kafonek DR, Brandenburg S, Wu Y, He X, Powe NR and Feinberg AP: Loss of IGF2 imprinting: a potential marker of colorectal cancer risk. Science 299: 1753-1755, 2003.

5. Vu TH, Li T, Nguyen D, Nguyen BT, Yao XM, Hu JF and Hoffman AR: Symmetric and asymmetric DNA methylation in the human IGF2-H19 imprinted region. Genomics 64: 132-143, 2000.

6. Bell A and Felsenfeld G: Methylation of a CTCF-dependent boundary controls imprinted expression of the Igf2 gene. Nature 405: 482-485, 2000.

7. Hark AT, Schoenherr CJ, Katz DJ, Ingram RS, Levorse JM and Tilghman SM: CTCF mediates methylation-sensitive enhancerblocking activity at the H19/Igf2 locus. Nature 405: 486-489, 2000 . 
8. Szabo P, Tang SH, Rentsendorj A, Pfeifer GP and Mann JR: Maternal specific footprints at putative CTCF sites in the H19 imprinting control region give evidence for insulator function. Curr Biol 10: 607-610, 2000.

9. Cui H, Niemitz EL, Ravenel JD, Onyango P, Brandenburg SA, Lobanenkov VV and Feinberg AP: Loss of imprinting of insulin-like growth factor-II in Wilms' tumor commonly involves altered methylation but not mutations of CTCF or its binding site. Cancer Res 61: 4947-4950, 2001.

10. Ulaner GA, Yang Y, Hu JF, Li T, Vu TH and Hoffman AR: CTCF binding at the insulin-like growth factor-II (IGF2)/H19 imprinting control region is insufficient to regulate IGF2/H19 expression in human tissues. Endocrinology 144: 4420-4426, 2003.

11. Nakagawa H, Nuovo GJ, Zervos EE, Martin EW Jr, Salovaara R, Aaltonen LA and de la Chapelle A: Age-related hypermethylation of the 5' region of MLH1 in normal colonic mucosa is associated with microsatellite-unstable colorectal cancer development. Cancer Res 61: 6991-6995, 2001.

12. Feinberg AP: Cancer epigenetics takes center stage. Proc Natl Acad Sci USA 98: 392-394, 2001.

13. Takai D, Gonzales FA, Tsai YC, Thayer MJ and Jones PA: Large scale mapping of methylcytosines in CTCF-binding sites in the human H19 promoter and aberrant hypomethylation in human bladder cancer. Hum Mol Genet 10: 2619-2626, 2001.

14. Fu VX, Dobosy JR, Desotelle JA, Almassi N, et al: Aging and cancer-related loss of insulin-like growth factor 2 imprinting in the mouse and human prostate. Cancer Res 68: 6797-6802, 2008 .

15. Murrell A, Heeson S and Reik W, et al: Interaction between differentially methylated regions partitions the imprinted genes Igf2 and H19 into parent-specific chromatin loops. Nat Genet 36: 889-893, 2004

16. Jemal A, Siegel R, Ward E, Murray T, Xu J, Smigal C and Thun MJ: Cancer statistics. CA Cancer J Clin 56: 106-130, 2006

17. Bunting PS: Screening for prostate cancer with prostatespecific antigen: beware the biases. Clin Chim Acta 315: 71 97, 2002.

18. Manoharan M, Ramachandran K, Soloway MS and Singal R: Epigenetic targets in the diagnosis and treatment of prostate cancer. Int Braz J Urol 33: 11-18, 2007.

19. Wells J and Farnham PJ: Characterizing transcription factor binding sites using formaldehyde crosslinking and immunoprecipitation. Methods 26: 48-56, 2002.

20. Jarrard DF, Bussemakers MJ, Bova GS and Isaacs WB: Regional loss of imprinting of the insulin-like growth factor II gene occurs in human prostate tissues. Clin Cancer Res 1: 1471-1478, 1995.

21. Pant V, Kurukuti S, Pugacheva E, et al: Mutation of a single CTCF target site within the H19 imprinting control region leads to loss of Igf2 imprinting and complex patterns of de novo methylation upon maternal inheritance. Mol Cell Biol 24: 3497-3504, 2004.

22. Szabo PE, Tang SH, Silva FJ, Tsark WM and Mann JR: Role of CTCF binding sites in the Igf2/H19 imprinting control region. Mol Cell Biol 24: 4791-4800, 2004.

23. Esteves LI, Javaroni AC, Nishimoto IN, et al: DNA methylation in the CTCF-binding site I and the expression pattern of the H19 gene: does positive expression predict poor prognosis in early stage head and neck carcinomas? Mol Carcinog 44: 102-110 2005 .
24. Hancock AL, Brown KW, Moorwood K, et al: A CTCF-binding silencer regulates the imprinted genes AWT1 and WT1-AS and exhibits sequential epigenetic defects during Wilms' tumourigenesis. Hum Mol Genet 16: 343-354, 2007.

25. Cooper MJ, Fischer M, Komitowski D, et al: Developmentally imprinted genes as markers for bladder tumor progression. J Urol 155: 2120-2127, 1996.

26. Cho NY, Kim BH, Choi M, et al: Hypermethylation of $\mathrm{CpG}$ island loci and hypomethylation of LINE-1 and Alu repeats in prostate adenocarcinoma and their relationship to clinicopathological features. J Pathol 211: 269-277, 2007.

27. Ellinger J, Bastian PJ, Jurgan T, et al: CpG island hypermethylation at multiple gene sites in diagnosis and prognosis of prostate cancer. Urology 71: 161-167, 2008.

28. Murell A: Genomic imprinting and cancer: from primordial germ cells to somatic cells. Scientific World J 6: 1888-1910, 2006.

29. Fahrner JA, Eguchi S, Herman JG and Baylin SB: Dependence of histone modifications and gene expression on DNA hypermethylation in cancer. Cancer Res 62: 7213-7218, 2002.

30. Nguyen TT, Cho K, Stratton SA and Barton MC: Transcription factor interactions and chromatin modifications associated with p53-mediated, developmental repression of the alpha-fetoprotein gene. Mol Cell Biol 25: 2147-2157, 2005.

31. Dobosy JR, Fu VX, Desotelle JA, et al: A methyl-deficient diet modifies histone methylation and alters Igf2 and $\mathrm{H} 19$ repression in the prostate. Prostate 68: 1187-1195, 2008.

32. Guan M, Zhou X, Soulitzis N, Spandidos DA and Popescu NC: Aberrant methylation and deacetylation of deleted in liver cancer-1 gene in prostate cancer: potential clinical applications. Clin Cancer Res 12: 1412-1419, 2006.

33. Das PM, Ramachandran K, Vanwert J, Ferdinand L, Gopisetty G, Reis IM and Singal R: Methylation mediated silencing of TMS1/ASC gene in prostate cancer. Mol Cancer 5: 28, 2006.

34. Reibenwein J, Pils D and Horak P: Promoter hypermethylation of GSTP1, AR, and 14-3-3sigma in serum of prostate cancer patients and its clinical relevance. Prostate 67: 427-432, 2007.

35. Seligson DB, Horvath S, Shi T, Yu H, Tze S, Grunstein M and Kurdistani SK: Global histone modification patterns predict risk of prostate cancer recurrence. Nature 435: 1262-1266, 2005.

36. Ferdinandusse S, Denis S, Ijlst L, Dacremont G, Waterham HR and Wanders RJ: Subcellular localization and physiological role of alpha-methylacyl-CoA racemase. J Lipid Res 41: 1890-1896, 2000.

37. Xu J, Kalos M, Stolk JA, et al: Identification and characterization of prostein, a novel prostate-specific protein. Cancer Res 61: 1563-1568, 2001

38. Luo J, Duggan DJ, Chen Y, et al: Human prostate cancer and benign prostatic hyperplasia: molecular dissection by gene expression profiling. Cancer Res 61: 4683-4688, 2001.

39. Bull JH, Ellison G, Patel A, et al: Identification of potential diagnostic markers of prostate cancer and prostatic intraepithelial neoplasia using cDNA microarray. Br J Cancer 84: 1512-1519, 2001.

40. Luo JH: Gene expression alterations in human prostate cancer. Drugs Today (Barc) 38: 713-719, 2002. 